\title{
Perceptions of Job Security in EuRope's AGEING WORKFORCE
}

Karsten Hank und Marcel Erlinghagen

176-2009

() $\boldsymbol{m e a - M a n n h e i m ~ R e s e a r c h ~ I n s t i t u t e ~ f o r ~ t h e ~ E c o n o m i c s ~ o f ~ A g i n g ~}$

L13, 17_D-68131 Mannheim_Phone +49 621 181-2773/1862_Fax +49 621 181-1863_www.mea.uni-mannheim.de 


\title{
Perceptions of Job Security in Europe's Ageing Workforce
}

\author{
Karsten Hank ${ }^{\mathrm{a}}$ \\ MEA - University of Mannheim \\ Marcel Erlinghagen \\ IAQ - University of Duisburg-Essen
}

\begin{abstract}
Using data from the 2004 Survey of Health, Ageing and Retirement in Europe, this paper investigates older workers' perceptions of job security in eleven countries. We describe cross-national patterns and estimate multilevel models to analyse individual and societal determinants of self-perceived job security in the older labour force. While there are considerable cross-country variations around a median value of $23 \%$ of workers aged 50 or older ranking their job security as poor, none of our suggested macro-level variables labour force participation rate, employment protection legislation, mean level of general social trust, and proportion disapproving of working beyond age 70 - bears statistically significant associations with individuals' job security. Future research should aim at identifying statistically more powerful indicators of the supposed multilevel relationship between social context and older workers' perceptions of job security. Moreover, supplementary findings indicate that further attention should be paid to the gender dimension of job insecurity.
\end{abstract}

\footnotetext{
${ }^{a}$ Corresponding author. Email: hank@mea.uni-mannheim.de.
} 


\section{Background}

There is a great deal of variation in older Europeans' participation in paid employment (as well as in unpaid productive activities; e.g., Erlinghagen \& Hank, 2006), suggesting a significant potential to reach the European Union's Lisbon target of a 50 percent labour force participation rate in the age group 55-64, even when accounting for differences in population health (cf. Alavina \& Burdorf, 2008; Brugiavni et al., 2005). However, globalisation has been shown to be a particular challenge for older workers in industrialised societies (e.g., Blossfeld et al., 2006; Mendenhall et al., 2008). On the one hand, they often benefit from better employment protection regulations than younger workers, but, on the other hand, they almost certainly face greater difficulties in finding adequate new employment if they loose their jobs, because employers tend to discriminate against older workers, perceiving them as less flexible, less productive, and therefore as more costly (e.g., Taylor \& Walker, 1994; Van Dalen et al., 2009). Moreover, early retirement programmes, which many countries offered as a convenient and financially relatively wellbuffered exit route from employment in the past (e.g., Kohli et al., 1991), have become substantially less generous in more recent years due to the pressure of population ageing on public pension systems (cf. Gruber \& Wise, 2004).

Having a continuous work-history until reaching legal retirement age is thus gaining further importance in ensuring an adequate retirement income. Also, as more people delay childbearing well into their 30s and as the time children remain dependent tends to increase (resulting from longer years spent in the educational system), a significant proportion of workers will continue to have child-related financial obligations until approaching traditional retirement ages (e.g., Hank, 2004). This is likely to increase particularly older workers fear of loosing their job in today's globalised new economy (e.g., Sweet, 2007; also see Fullerton \& Wallace, 2007), because their opportunities to compensate financial losses resulting from unemployment, such as reduced retirement benefits, through future employment are very limited. Although some studies suggest that workers' actual job stability may have declined less over the course of the last two or three decades of the $20^{\text {th }}$ 
century than some might have expected (e.g., Doogan, 2001; Erlinghagen \& Knuth, 2004 also see Fevre, 2007), older workers may still be psychologically and socially less equipped than their younger counterparts to cope with the perceived hazards of job loss, being raised in a different generational context. Thus, in addition to particular concerns about their economic well-being during old age, older workers may also suffer more from adverse effects of job insecurity on other outcomes related to individuals' quality of life, such as health (e.g., Ferrie, 2001) or family functioning (e.g., Larson et al., 1994).

Despite the fact that people's self-perceived job security is likely to vary across different institutional, economic, and cultural contexts, the number of studies addressing this issue by taking a cross-national perspective has remained small (see Anderson \& Pontusson, 2007; Erlinghagen, 2008; Green et al., 2000). ${ }^{1}$ Complementing this literature, we use data from the 2004 Survey of Health, Ageing and Retirement in Europe (SHARE) to investigate perceptions of job security in Europe's ageing workforce. The aim of our study is twofold. First, we will analyse cross-national patterns of self-perceived job security across the eleven Continental European countries represented in SHARE, which are

characterized by very different employment and welfare regimes. ${ }^{2}$ Second, applying multilevel regression analysis, we will investigate in how far individual and societal factors which previous research identified as potential determinants of self-perceived job security in the overall workforce - such as workers' resource endowment, workplace characteristics, or labour market conditions - bear similar associations in the older labour force.

\section{Conceptual issues and hypotheses}

The issue of changes in job security and job stability is one of great interest for the scientific as well as for the general public (see, for example, Kalleberg, 2009). Despite the considerable knowledge that has been accumulated so far, the terms 'job security' and 'job stability' still tend to be used almost synonymously in many public debates. However, while job stability and job security clearly bear a positive association, voluntary job-to-job mobility, which has a substantial impact on conventional measures of job stability, is very 
different from involuntary job turnover, regarding both its individual consequences and its social policy implications (e.g., Royalty, 1998; Sousa-Poza, 2004). Thus, researchers and the general public should be careful not to mix-up job stability and job security, but to treat them as conceptually distinct issues.

Moreover, uncertainty about one's future employment may take different forms which can be measured in a variety of ways (e.g., Charles \& James, 2003; Klandermans \& Van Vuuren, 1999). For example, objective indicators of insecurity, such as the level of layoffs and dismissals, need to be distinguished from the individual's subjective perception of job security (e.g., Anderson \& Pontusson 2007; De Witte \& Näswall, 2003). Whether a worker is concerned about the continuation of her or his job is supposed to be determined by individual and societal characteristics (cf. Erlinghagen, 2008; Näswall \& De Witte, 2003).

At the micro level, the individual's resources - such as his or her skill-level - should heavily influence both the actual employment status and the perception of one's job insecurity. Particularly in the older labour force, this might result in some sort of 'selection', because those workers who are in employment still are likely to exhibit specific characteristics which made them more likely to 'survive' on the labour market than their retired (or unemployed) counterparts of the same age who, consequently, cannot report on their job security anymore. Thus, we cannot conclude from the results of our analysis what the level of subjective job insecurity in a country would be if all older workers were participating in the labour force. ${ }^{3}$ Moreover, we might expect that in our study population of 'survivors' the propensity to perceive one's job as insecure might actually decrease with increasing age, despite a relatively poor employment situation of older people in general.

Also to be expected are interactions with gender arising out of still existing role differences, gender-based specialisation and the associated (statistical) discrimination against women. In addition certain household characteristics have been discussed as important factors entering the evaluation of one's job security. Because of their responsibility for children, parents in particular are likely to react more sensitively to 
threats to their employment situation than those without children. Furthermore, it is reasonable to suppose that a precarious household financial situation heightens perceived job insecurity, since the potential loss of a job becomes a threat to the family's very livelihood. In addition, size of firm and sector effects need to be considered. Employees of larger firms should be less likely to experience job insecurity because of the greater importance of internal labour markets and their company's greater powers of resistance in periods of economic difficulty. Such considerations suggest that self-perceived job insecurity declines with size of firm. Further on it can be assumed that employees in the public sector will experience higher job security (see Erlinghagen, 2008, for a comprehensive literature overview).

Relevant macro-level properties should be conceived of as "limiting frames of reference” (Münch \& Smelser, 1987: 381) defining the situation in which the individual develops his or her expectations about the future. One may distinguish economic reference frames (e.g. labour market conditions), legal reference frames (e.g. employment protection legislation), cultural reference frames (e.g. levels of social trust), and social reference frames (e.g. conventions about work-related age boundaries).

Since our study's focus is on the subjective aspect of older Europeans' job security, the socio-cultural context should be of particular importance, because there is ample evidence suggesting the existence of social and cultural differences in 'learned' fears and anxieties (e.g., Higgins, 2004; also see Erlinghagen, 2008). That is, the individual's interpretation of given labour market conditions - and of changes therein - varies with personal characteristics and is culturally shaped: "some will have feelings of uncertainty which are unfounded from an 'objective' point of view, whereas others, on the contrary, will feel that their job is secure, even though they may be dismissed in the near future.” (De Witte \& Näswall, 2003: 156).

While we propose no explicit hypotheses in how far previously identified determinants of self-perceived job security in the overall workforce bear similar associations in the older labour force, we will test four hypotheses concerning the 
relationship between older workers’ perceptions of job insecurity and specific country-level properties:

(1) Individuals living in countries characterised by less favourable labour market conditions for older workers - reflected, for example, in a lower labour force participation rate - will perceive their job security as poor, relative to workers facing better employment opportunities.

(2) In a legal setting that does not support stable employer-employee relations through, for example, high levels of formal employment protection, older workers will perceive their job security as poor, relative to their counterparts in countries with stricter employment protection regulations.

(3) Older workers living in countries characterised by lower levels of social trust will perceive their job security as poor, relative to individuals exposed to a cultural context in which social trust - as a basis for a high informal commitment between employers and employees and for the functioning of implicit employment contracts (cf. Rosen, 1985) - is more strongly developed.

(4) Individuals who are at a higher risk of being exposed to age discrimination on the labour market (e.g., Weller, 2007), which could be reflected, for example, in more restrictive social conventions regarding older people’s employment, will perceive their job security as poor, relative to those living in countries in which attitudes towards elders' participation in the labour market are more positive.

\section{Data \& method}

Sample. We use data from Release 2.0.1 of the 2004 Survey of Health, Ageing, and Retirement in Europe (SHARE; cf. Börsch-Supan et al., 2005), which is closely modelled after the English Longitudinal Study of Ageing and the U.S. Health and Retirement Study. It is the first representative dataset to provide extensive standardized information on the socio-economic status, health, and family relationships of older people in eleven 
Continental European countries (Sweden, Denmark, Germany, The Netherlands, Belgium, France, Switzerland, Austria, Italy, Spain, and Greece). ${ }^{4}$

The average household response rate was 60\%, ranging from 39\% in Belgium and Switzerland to $79 \%$ in France. In the bivariate descriptive analysis we apply weights calibrated against the total national population by age group and gender, which - to some extent - also compensates for unit nonresponse (see de Luca \& Peracchi, 2005, and Klevmarken et al., 2005, for details). From the originally more than 27,000 personal interviews with people aged 50 or older, we included 5,355 observations in our analytic sample, which we restricted to individuals aged 50 to 67 , excluding civil servants, the selfemployed, retirees, and others reporting not to be working at the time of the interview (mostly unemployed and housewives).

Dependent variable. As part of a short battery of items assessing overall quality of work (cf. Siegrist et al., 2007, for details), SHARE respondents were asked, to which degree they agree or disagree with the statement: "My job security is poor." From the originally four answer categories, we constructed a binary indicator of job security, which equals 1 , if they (fully) agreed, 0 if they (fully) disagreed.

Control variables (see Table 1 for descriptive sample statistics). We include a set of standard control variables in our analysis, which ample previous research showed to be theoretically and empirically relevant (e.g., Erlinghagen, 2008). Next to potentially relevant demographic variables (age, sex), this set includes indicators of the individual's resource endowment (self-perceived general health, years of education, as well as job tenure and its square), his or her workplace conditions (fixed-term contract, part-time work, employment in the public sector, firm size), and some basic information on the household (whether the household makes ends meet and whether co-residing children are present).

In addition, we account for four macro-level indicators ${ }^{5}$ : First, economic reference frames are operationalised by the labour force participation rate in the population aged 5564 (obtained from Eurostat for the year 2005). Second, legal reference frames are operationalised by the 2003 OECD Employment-Protection-Legislation Indicator. This 
indicator is based on 18 items covering three main areas: employment protection of regular workers against individual dismissal, specific requirements for collective dismissals, and regulations of temporary forms of employment (cf. OECD 2004). Third, cultural reference frames are operationalised by people's mean level of general social trust, based on a scale from 0 to 10 (obtained from the European Social Survey 2002-03; see http://www.europeansocialsurvey.org). Fourth, and finally, social reference frames are operationalised by a measure of conventions about work-related age boundaries, namely the proportion of respondents in the European Social Survey (2006-07) disapproving of people working beyond the age of 70 . Note that this information is not available for Greece and Italy, which therefore have to be excluded from this part of the analysis. Also, because the relatively small number of countries covered in SHARE prohibits the inclusion of more than one macro-level indicator at a time, we estimate separate models for each of these variables. ${ }^{6}$

\section{[Table 1 about here]}

Method. We use STATA 10 to estimate random intercept multilevel models for binary dependent variables (cf. Guo \& Zhao, 2000; Snijders \& Bosker, 1999: Chapter 4). That is, in the analysis performed here, all regression coefficients other than the intercept are constrained to be fixed across countries, i.e. we assume that the effect of the explanatory variables does not differ between contexts. The equation for this kind of model is

$$
\mathrm{y}_{\mathrm{ij}}=\mathrm{b}_{0}+\mathrm{b}_{1} \mathrm{x}_{\mathrm{ij}}+\mathrm{b}_{2} \mathrm{~V}_{\mathrm{j}}+\mathrm{u}_{0 \mathrm{j}}+\varepsilon_{\mathrm{ij}}
$$

where $\mathrm{y}_{\mathrm{ij}}$ represents the outcome of the dependent variable $\mathrm{y}$ for individual $\mathrm{i}$ within country $\mathrm{j}, \mathrm{x}_{\mathrm{ij}}$ is the individual-level explanatory variable, and $\mathrm{v}_{\mathrm{j}}$ the macro-level explanatory variable. The random intercept's fixed component $b_{0}$ and the slopes $b_{1}$ and $b_{2}$ are the parameters of the equation. The error term is more complex than in traditional regression equations, since it includes not only the micro error $\varepsilon_{\mathrm{ij}}$, but also a macro error $\mathrm{u}_{0 \mathrm{j}}$. The latter indicates that the intercept may vary across countries, i.e. $\mathrm{u}_{0 \mathrm{j}}$ measures the deviation of each context from $b_{0}$ (between-context variance). It captures otherwise unobserved context 
effects and accounts for the correlation between individuals nested within the same country. All $\varepsilon_{\mathrm{ij}}$ are assumed to be independent of each other with expectation zero and variance $\sigma_{\varepsilon}^{2}$. The macro-level disturbances $\mathrm{u}_{0 \mathrm{j}}$ are independent of the individual-level disturbances, have expectation zero and variance $\sigma_{u}^{2}$. If the variance of $\mathrm{u}_{0 \mathrm{j}}$ turns out to be statistically significant from zero, context effects are present.

Multilevel generalized linear models (GLIM) can be used to overcome some of the shortcomings of simple random coefficient models, such as the underlying assumption of a normal error distribution. Hierarchical GLIM therefore allows the application of multilevel logistic regression models for the analysis of discrete dependent variables. The two-level model for a binary response variable is conceptually equivalent to equation [1]. The probability of the binary outcome to be 1 is defined as $p_{i j}=\operatorname{Pr}\left(y_{i j}=1\right)$, where $p_{i j}$ is modeled using a logit link function. With the standard assumption that $\mathrm{y}_{\mathrm{ij}}$ has a Bernoulli distribution, the multilevel logistic model can be written as

$$
\log \left[\mathrm{p}_{\mathrm{ij}} /\left(1-\mathrm{p}_{\mathrm{ij}}\right)\right]=\mathrm{b}_{0}+\mathrm{b}_{1} \mathrm{x}_{\mathrm{ij}}+\mathrm{b}_{2} \mathrm{v}_{\mathrm{j}}+\mathrm{u}_{0 \mathrm{j}}+\varepsilon_{\mathrm{ij}}
$$

where the same assumptions as in the case of multilevel linear models apply to $u_{0 j}$, i.e. the random effect is assumed to be normally distributed, with expected value 0 and variance $\sigma_{u}^{2}$. - The results of the logistic regressions in Table 3 are presented as odds ratios.

\section{Results}

\section{Descriptive findings}

The median share of older workers reporting that their job security is poor is $23 \%$ (see Table 2). A closer inspection does not reveal any clear geographical pattern of high or low proportions of workers perceiving their jobs as insecure. The lowest values are found in Sweden (18\%) and Spain (19\%), whereas Italy (33\%) and the Netherlands (34\%) exhibit the highest ones, except for Greece, which is an extreme outlier with $49 \%$ of older workers reporting a poor job security. The share of workers perceiving their jobs as insecure tends 
to be higher among older men than among women (see Table 2), particularly so in Austria (28\% vs. 15\%), but also in Belgium, the Netherlands, and Italy.

[Table 2 about here]

A bivariate descriptive analysis of older workers' self-perceived job security and the four proposed macro-level variables (see Figure 1) provides moderate support, at the aggregate level, for most of the cross-level hypotheses formulated above (the association between job security and level of employment protection being an exception). The strongest correlation is observed between job security and the mean level of general social trust $\left(\mathrm{r}^{2}=\right.$ 0.37), followed by the labour force participation rate $\left(r^{2}=0.14\right)$.

[Figure 1 about here]

\section{Multivariate results}

The right-hand side variables are included stepwise into the regression, that is, we start with a so called 'empty' model that contains nothing but the constant and the macro-level error term (Model 1). The micro-level variables are included in Model 2, which is complemented by the various macro-level indicators in Models 3a-3d.

Model 1 clearly indicates a statistically significant regional variation of the constant. The proportion of the total variance due to variance between countries (i.e. the 'betweencontext variance'), which is subsequently denoted as $\rho$, amounts to about $4.5 \%$ in the empty model. When introducing the micro-level control variables in Model 2, demographic characteristics and the individual's resource endowment are found to play an important role in the formation of expectations about one's future employment. Women and older workers, especially those aged 61 or over, are shown to be less likely to perceive their job security as poor, whereas those whose general health is 'fair or worse' exhibit significantly higher risks of job insecurity. More highly educated workers are less likely to report poor job security and job tenure bears an almost linear negative association with job insecurity. Turning to work place characteristics, we do not detect any statistically significant correlations if part-time employment, public sector employment, or firm seize are 
considered. However, having a fixed-term contract is associated with a substantially higher risk of self-perceived job insecurity among older workers. With regard to household characteristics, the presence of children does not contribute to explaining variations in older workers' perception of job security, whereas a situation in which it is difficult to make ends meet is paralleled by and increased odds of feeling insecure about one's employment prospects. We observe barely any reduction in $\rho$, that is, population composition - as it is accounted for in Model 2 - does not explain the observed betweencontext variance.

The coefficients of the micro-level variables remain unchanged in Models $3 a$-3d, that is, if the labour force participation rate, the overall levels of employment protection and general social trust, or the proportions of respondents (in the European Social Survey) stating disapproval of working past age 70 are controlled for. It turns out that these macrolevel variables are neither significantly correlated with individuals' self-perceived job security, nor do they contribute to a substantial reduction of $\rho$ (which takes its lowest value of 3.6\% in Model 3c, where we account for countries' mean level of general social trust) . That is, statistically significant portions of unexplained variance between countries remain in all models (including Model $3 d$, which we ran on a subsample covering nine SHARE countries only, therefore resulting in a smaller $\rho$ ).

[Tables 3 about here]

\section{Discussion}

Our analysis of perceptions of job security in Europe's ageing workforce, which is based on data from the 2004 Survey of Health, Ageing and Retirement in Europe, identified considerable cross-country variations around a median value of $23 \%$ of workers aged 50 or older ranking their job security as poor. While the potential role of labour market conditions in explaining such variations was already addressed in previous research (e.g., Anderson \& Pontusson 2007; Erlinghagen, 2008), the present study of eleven Continental 
European countries is the first one that linked empirically specific macro-indicators of social and cultural reference frames to individuals’ self-perceived job security.

However, none of our hypotheses concerning the relationship between older workers' perceptions of job insecurity and particular country-level properties was confirmed. Although the proportion of the total variance due to variance between countries tends to be relatively small (about 4\%) and although the connection between personal traits and cultural dimensions is particularly difficult to tackle empirically (e.g., Hofstede \& McCrae, 2004), future research should aim at identifying statistically more powerful indicators of the supposed multilevel relationship between social context and (older) workers’ perceptions of their job security (also see Erlinghagen, 2008: 193f.).

Also, more refined measures of subjective job security might provide new insights. Building on recent psychological research, Anderson \& Pontusson (2007: 214), for example, suggest to distinguish 'cognitive job insecurity', which “is an individual's estimate of the probability that he or she will loose their job in the near future”, from ‘affective job insecurity’, which “refers to worry or anxiety about loosing one’s job”. While the latter is considered to be a function of the former and individuals' perception of the consequences of losing their job, the two dimensions of subjective job security might be affected in different ways by properties of older workers' social context.

Moreover, further attention should be paid to the gender dimension of job insecurity. Our descriptive findings support previous evidence suggesting that women are generally less concerned about job security than men (e.g., Charles \& James, 2003). When running separate regressions for men and women (details not shown here) we also detected weak interaction effects between gender and individuals' resources (e.g. education and health). The most interesting finding from this sex-specific analysis is, however, that male workers are more likely to perceive their job security as poor if they are co-residing with children independent of the actual economic situation of the household. This might reflect that fathers of co-resident children who loose their job would also loose their traditional provider role, making them more sensitive to potential job loss (see Charles \& James, 2005, 
for a related discussion). Women's perception of job security, however, remains unaffected by the presence of children, but worsens only if the household faces financial hardship.

Finally, once longitudinal SHARE data for an even greater variety of countries will become available (cf. Börsch-Supan et al., forthcoming), researchers will be able to study the dynamics of self-perceived job security in Europe's ageing workforce. This pertains to both the potential role of changes in individuals' personal circumstances (e.g. their health condition or family situation) and to the important question of whether the observed differences between countries will change along with the globalisation and population ageing processes.

\section{Acknowledgements}

The SHARE data collection was primarily funded by the European Commission through the 5th framework program (project QLK6-CT-2001-00360 in the thematic program Quality of Life). Additional funding came from the U.S. National Institute on Ageing (U01 AG09740-13S2, P01 AG005842, P01 AG08291, P30 AG12815, Y1-AG-4553-01 and

OGHA 04-064). Data collection in Austria (through the Austrian Science Foundation, FWF), Belgium (through the Belgian Science Policy Office) and Switzerland (through BBW/OFES/UFES) was nationally funded. Further support by the European Commission was provided through the 6th framework program (projects SHARE-I3, RII-CT-2006062193, and COMPARE, CIT5-CT-2005-028857).

\section{References}

Alavinia, S.M., Burdorf, A. (2008): Unemployment and Retirement and Ill-health: A Crosssectional Analysis across European Countries. International Archives of Occupational and Environmental Health, 82 (1), 39-45.

Anderson, C.J., Pontusson, J. (2007): Workers, Worries and Welfare States: Social Protection and Job Insecurity in 15 OECD Countries. European Journal of Political Research, 46 (2), 211-235. 
Angus, J., Reeve, P. (2006): Ageism: A Threat to “Aging Well” in the $21^{\text {st }}$ Century, Journal of Applied Gerontology, 25, 137-152.

Banks, J., Casanova, M. (2003): Work and retirement, in: M. Marmot et al. (eds.), Health, Wealth and Lifestyles of the Older Population in England: The 2002 English Longitudinal Study of Ageing. IFS: London, 127-166.

Blossfeld, H.-P., Buchholz, S., Hofäcker, D. (eds.) (2006): Globalization, Uncertainty and Late Careers in Society. Routledge: London.

Börsch-Supan, A., Brugiavini, A., Jürges, H., Mackenbach, J., Siegrist, J., Weber, G. (eds.) (2005): Health, Ageing and Retirement in Europe - First Results from the Survey of Health, Ageing and Retirement in Europe. MEA: Mannheim.

Börsch-Supan, A. \& Jürges, H. (eds.) (2005): The Survey of Health, Ageing and Retirement in Europe - Methodology. MEA: Mannheim.

Börsch-Supan, A., Hank, K., Jürges, H., Schröder, M. (forthcoming): Longitudinal Data Collection in Continental Europe: Experiences from the Survey of Health, Ageing and Retirement in Europe, in: Janet Harkness et al. (eds.), Survey Methods in Multinational, Multiregional and Multicultural Contexts. John Wiley \& Sons: Hoboken, NJ.

Brugiavini, A., Croda, E., Mariuzzo, F. (2005): Labour force participation of the elderly: Unused capacity?, in: A. Börsch-Supan et al. (eds.), Health, Ageing and Retirement in Europe - First Results from the Survey of Health, Ageing and Retirement in Europe. MEA: Mannheim, 236-240.

Charles, N., James, E. (2003): The Gender Dimensions of Job Insecurity in a Local Labour Market. Work, Employment \& Society, 17 (3), 531-552.

Charles, N., James, E. (2005): 'He earns the bread and butter and I earn the cream': Job Insecurity and the Male Breadwinner Family in South Wales. Work, Employment \& Society, 19 (3), 481-502.

de Luca, G., Peracchi, F. (2005): Survey participation in the first wave of SHARE, in: A. Börsch-Supan \& H. Jürges. (eds.), The Survey of Health, Ageing and Retirement in Europe - Methodology. MEA: Mannheim, 88-104. 
De Witte, H., Näswall, K. (2003): 'Objective' vs. 'Subjective' Job Insecurity: Consequences of Temporary Work for Job Satisfaction and Organizational Commitment in Four European Countries. Economic and Industrial Democracy, 24 (2), 149-188.

Doogan, K. (2001): Insecurity and Long-term Employment. Work, Employment \& Society, 15, 419-441.

Erlinghagen, M. (2008): Self-Perceived Job Insecurity and Social Context: A Multi-Level Analysis of 17 European Countries. European Sociological Review, 24 (2), 183-197.

Erlinghagen, M., Hank, K. (2006): The Participation of Older Europeans in Volunteer Work. Ageing \& Society, 26 (4), 567-584.

Erlinghagen, M., Knuth, M. (2004): In Search of Turbulence: Labour Market Mobility and Job Stability in Germany. European Societies, 6 (1), 49-70.

Ferrie, J.E. (2001): Is Job Insecurity Harmful to Health? Journal of the Royal Society of Medicine, 94 (1), 71-76.

Fevre, R. (2007): Employment Insecurity and Social Theory: The Power of Nightmares. Work, Employment \& Society, 21 (3), 517-535.

Fullerton, A.S., Wallace, M. (2007): Traversing the Flexible Turn: US Workers' Perceptions of Job Security, 1977-2002. Social Science Research, 36 (1), 201-221.

Green, F., Felstead, A., Burchell, B. (2000): Job Insecurity and the Difficulty of Regaining Employment: An Empirical Study of Unemployment Expectations. Oxford Bulletin of Economics and Statistics, 62 (4), 855-884.

Gruber, J., Wise, D. (eds.) (2004): Social Security Programs and Retirement around the World: Micro-Estimation. University of Chicago Press: Chicago.

Guo, G., Zhao, H. (2000): Multilevel Modeling for Binary Data. Annual Review of Sociology 26, 441-462.

Hank, K. (2004): Effects of Early Life Family Events on Women's Late Life Labour Market Behaviour. European Sociological Review, 20 (3), 189-198.

Higgins, L. T. (2004): Cultural Effects on the Expression of Some Fears by Chinese and British Female Students. Journal of Genetic Psychology, 165 (1), 37-49. 
Hofstede, G., McCrae, R.R. (2004): Personality and Culture Revisited: Linking Traits and Dimensions of Culture. Cross-Cultural Research, 38 (1), 52-88.

Kalleberg, A.L. (2009): Precarious Work, Insecure Workers: Employment Relations in Transition. American Sociological Review, 74 (1), 1-22.

Klandermans, B., Van Vuuren, T. (1999): Job Insecurity: Introduction. European Journal of Work and Organisational Psychology, 8 (2), 145-153.

Klevmarken, A., Hesselius, P., Swensson, B. (2005): The SHARE sampling procedures and calibrated design weights, in: A. Börsch-Supan \& H. Jürges. (eds.), The Survey of Health, Ageing and Retirement in Europe - Methodology. MEA: Mannheim, 28-69.

Kohli, M., Rein, M., Guillemard, A.-M., van Gunsteren, H. (eds.) (1991): Time for Retirement: Comparative Studies of Early Exit from the Labor Force. Cambridge University Press: Cambridge.

Larson, J.H., Wilson, S.M., Beley, R. (1994): The Impact of Job Insecurity on Marital and Family Relationships. Family Relations, 43 (2), 138-143.

Maas, C.M., Hox, J.J. (2005): Sufficient Sample Sizes for Multilevel Modeling. Methodology, 1 (3), 85-91.

Mendenhall, R., Kalil, A., Spindel, L.J., Hart, C.M.D. (2008): Job Loss at Mid-life: Managers and Executives Face the "New Risk Economy”. Social Forces, 87 (1), 185209.

Münch, R., Smelser, N.J. (1987): Relating the Micro and Macro, in: J.C. Alexander et al. (eds.), The Micro-Macro Link, University of California Press: Berkeley, 356-388.

Näswall, K., De Witte, H. (2003): Who Feels Insecure in Europe? Predicting Job Insecurity from Background Variables. Economic and Industrial Democracy, 24 (2), 189-215.

OECD (2004): Employment protection regulation and labour market performance, in: OECD Employment Outlook. OECD: Paris, 61-125.

Pichler, F., Wallace, C. (forthcoming): What are the Reasons for Differences in Job Satisfaction across Europe? Individual, Compositional, and Institutional Explanations. European Sociological Review.

Rosen, S. (1985): Implicit Contracts: A Survey. Journal of Economic Literature, 23, 11441175. 
Royalty, A.B. (1998): Job-to-Job and Job-to-Nonemployment Turnover by Gender and Education Level. Journal of Labor Economics, 16 (2), 392-443.

Siegrist, J., Wahrendorf, M., von dem Knesebeck, O., Jürges, H., Börsch-Supan, A. (2007): Quality of Work, Well-Being and Intended Early Retirement of Older Employees Baseline Results from the SHARE Study. European Journal of Public Health, 17 (1), 62-68.

Snijders, T.A.B., Bosker, R.J. (1999): Multilevel Analysis: An Introduction to Basic and Advanced Multilevel Modeling. Sage: London.

Sousa-Poza, A. (2004): Job Stability and Job Security: a Comparative Perspective on Switzerland's Experience in the 1990s. European Journal of Industrial Relations, 10 (1), 31-49.

Sweet, S. (2007): The Older Worker, Job Insecurity, and the New Economy. Generations, $31(1), 45-49$.

Taylor, P.E., Walker, A. (1994): The Ageing Workforce: Employers' Attitudes towards Older People. Work, Employment \& Society, 8 (4), 569-591.

Van Dalen, H.P., Henkens, K., Schippers, J. (2009): Dealing with older workers in Europe: a comparative survey of employers attitudes and actions. Journal of European Social Policy, 19 (1), 47-60.

Weller, S.A. (2007): Discrimination, Labour Markets and the Labour Market Prospects of Older Workers: What Can a Legal Case Teach Us? Work, Employment \& Society, 21 (3), 417-437.

Whiting, E. (2005): The Labour Force Participation of Older People. Labour Market Trends, 112 (6), 285-296.

\section{Figures \& Tables}


Figure 1: Correlations between proportions of older workers perceiving their job security (JS) as poor and selected country-level properties

(a) Labour force participation 55-64 \& JS

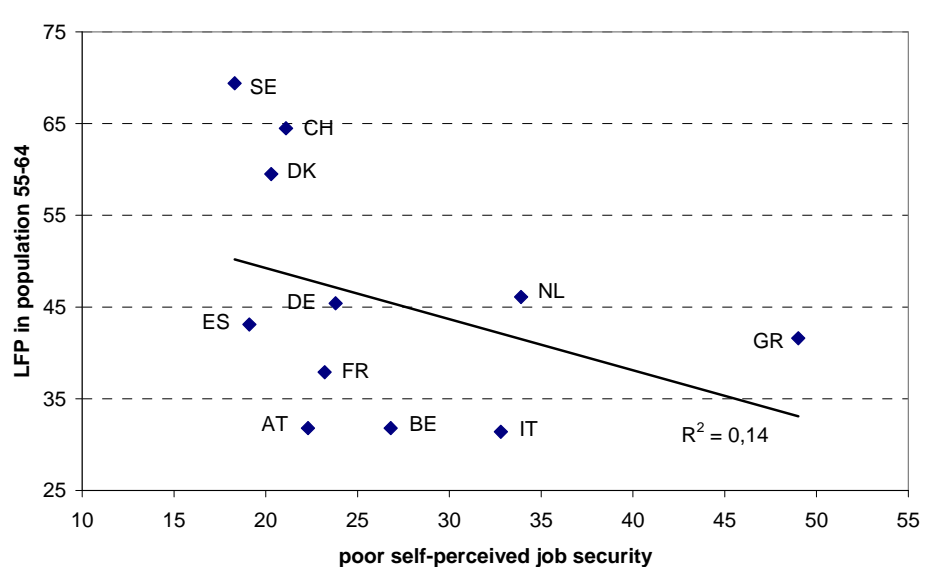

(c) Mean general social trust \& JS

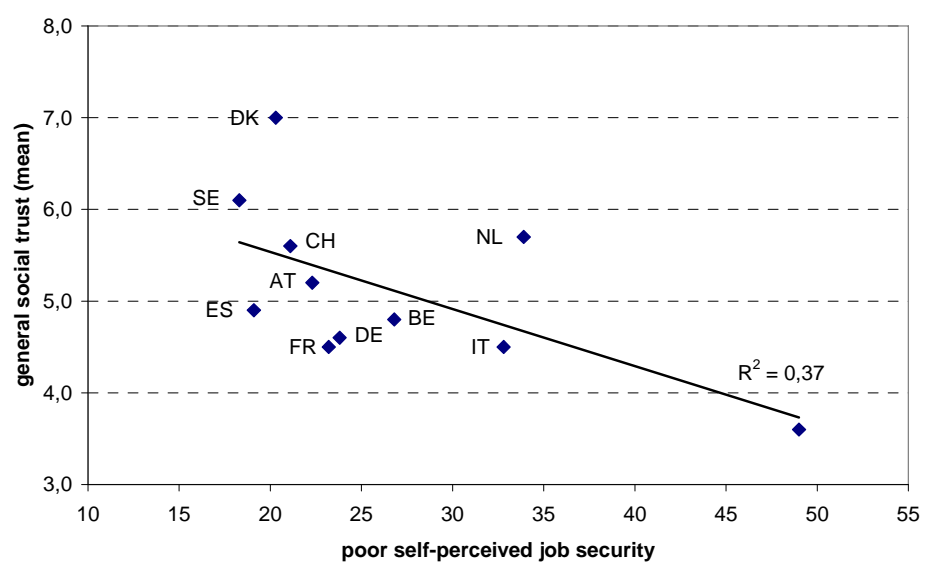

(b) Level of employment protection \& JS

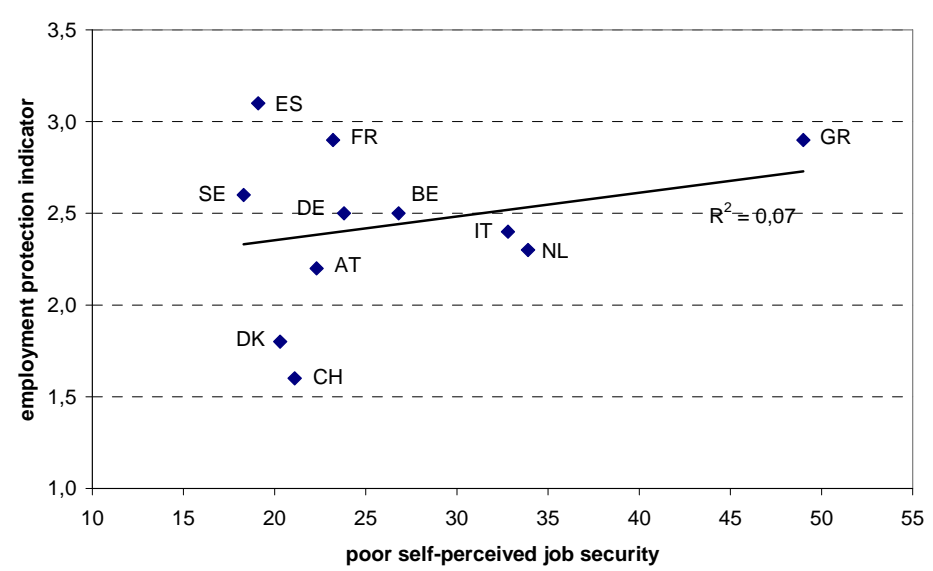

(d) Disapproval of working past age 70 \& JS

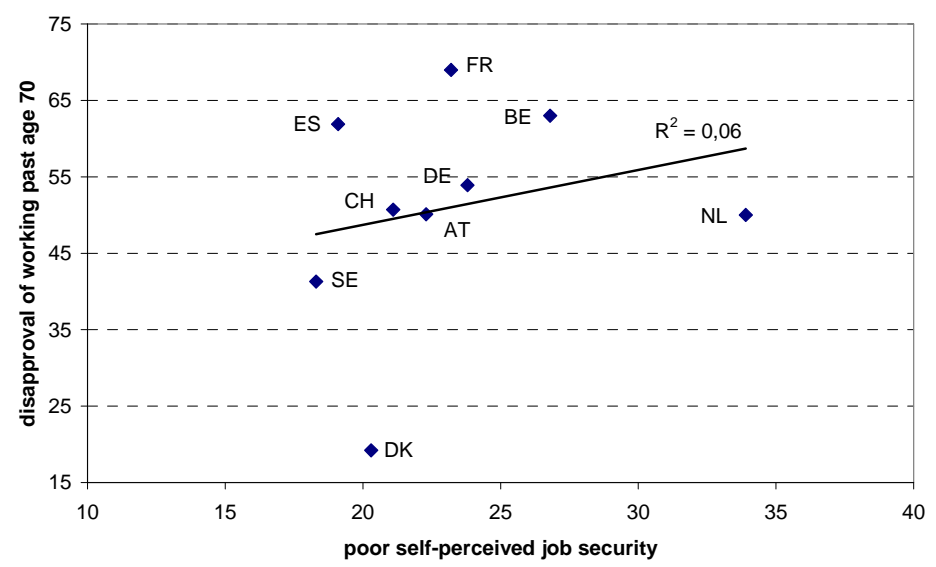

Source: SHARE 2004 (Release 2.0.1; weighted data), Eurostat, and European Social Survey; authors' representation.

$\mathrm{AT}=$ Austria, $\mathrm{BE}=$ Belgium, $\mathrm{CH}=$ Switzerland, $\mathrm{DE}=$ Germany, $\mathrm{DK}=$ Denmark $; \mathrm{ES}=$ Spain, $\mathrm{FR}=$ France, $\mathrm{GR}=$ Greece, $\mathrm{IT}=\mathrm{Italy}, \mathrm{NL}=\mathrm{Netherlands}, \mathrm{SE}=\mathrm{Sweden}$. 
Table 1: $\quad$ Descriptive sample statistics

\begin{tabular}{|c|c|}
\hline & Mean (standard deviation) ${ }^{\mathrm{a}}$ \\
\hline Self-perceived job security (poor) & $24 \%$ \\
\hline \multicolumn{2}{|l|}{ Demographics \& resource endowment } \\
\hline Gender (female) & $49 \%$ \\
\hline Age $50-54^{b}$ & $44 \%$ \\
\hline Age 55-60 & $42 \%$ \\
\hline Age 61-67 & $14 \%$ \\
\hline Self-perceived general health ('fair or worse’) & $20 \%$ \\
\hline Years of education & $11.7(3.8)$ \\
\hline Job tenure (years) & $18.7(12.8)$ \\
\hline Job tenure (years squared) & $516.0(536.7)$ \\
\hline \multicolumn{2}{|l|}{ Workplace characteristics } \\
\hline Fixed-term contract & $10 \%$ \\
\hline Part-time employment & $23 \%$ \\
\hline Public sector employment & $31 \%$ \\
\hline Less than 25 employees $^{\mathrm{b}}$ & $49 \%$ \\
\hline 25-199 employees & $31 \%$ \\
\hline 200-499 employees & $9 \%$ \\
\hline 500 employees or more & $10 \%$ \\
\hline \multicolumn{2}{|l|}{ Household situation } \\
\hline Child(ren) in household & $37 \%$ \\
\hline Difficulties to make ends meet & $19 \%$ \\
\hline
\end{tabular}

Source: SHARE 2004 (Release 2.0.1), authors' calculations. ${ }^{a}$ No standard deviation is displayed for binary variables. 
Table 2: $\quad$ Proportions of older workers perceiving their job security (JS) as poor, by country and sex, in percent

\begin{tabular}{|c|c|c|c|}
\hline Country & $\begin{array}{c}\text { Total proportion of } \\
\text { poor JS }\end{array}$ & $\begin{array}{c}\text { Proportion of } \\
\text { poor JS in men }\end{array}$ & $\begin{array}{c}\text { Proportion of } \\
\text { poor JS in women }\end{array}$ \\
\hline Sweden $(\mathrm{n}=1,109)$ & 18.3 & 18.0 & 18.6 \\
\hline Spain $(n=331)$ & 19.1 & 18.8 & 19.7 \\
\hline Denmark $(n=473)$ & 20.3 & 22.0 & 18.5 \\
\hline Switzerland $(\mathrm{n}=283$ ) & 21.1 & 24.1 & 17.8 \\
\hline Austria $(\mathrm{n}=278)$ & 22.3 & 28.4 & 15.0 \\
\hline France $(n=534)$ & $23.2^{\mathrm{a}}$ & 23.1 & 23.3 \\
\hline Germany $(\mathrm{n}=721)$ & 23.8 & 24.1 & 23.5 \\
\hline Belgium (n = 531) & 26.8 & 31.1 & 21.4 \\
\hline Italy $(\mathrm{n}=202)$ & 32.8 & 35.9 & 27.0 \\
\hline Netherlands ( $\mathrm{n}=601$ ) & 33.9 & 37.7 & 28.2 \\
\hline Greece $(n=292)$ & 49.0 & 48.5 & 49.9 \\
\hline
\end{tabular}

Source: SHARE 2004 (Release 2.0.1; weighted data), authors’ calculations. ${ }^{a}$ Median value. 
Table 3: $\quad$ Results of logistic multilevel models for 'poor job security'a ,

\begin{tabular}{|c|c|c|c|c|c|c|}
\hline & Model 1 & Model 2 & $\begin{array}{c}\text { Model } \\
3 a\end{array}$ & $\begin{array}{c}\text { Model } \\
3 b\end{array}$ & $\begin{array}{c}\text { Model } \\
3 c\end{array}$ & $\begin{array}{c}\text { Model } \\
3 d\end{array}$ \\
\hline \multicolumn{7}{|l|}{$\begin{array}{l}\text { Demographics \& } \\
\text { resource endowment }\end{array}$} \\
\hline Gender (female) & & $\begin{array}{l}0.716^{* *} \\
(-4.38)\end{array}$ & $\begin{array}{l}0.715^{* *} \\
(-4.39)\end{array}$ & $\begin{array}{l}0.716^{* *} \\
(-4.38)\end{array}$ & $\begin{array}{l}0.715^{* *} \\
(-4.40)\end{array}$ & $\begin{array}{l}0.717 * * \\
(-4.06)\end{array}$ \\
\hline Age $50-54^{b}$ & & 1.000 & 1.000 & 1.000 & 1.000 & 1.000 \\
\hline Age 55-60 & & $\begin{array}{l}0.760 * * \\
(-3.66)\end{array}$ & $\begin{array}{l}0.761^{* *} \\
(-3.66)\end{array}$ & $\begin{array}{l}0.761^{* *} \\
(-3.66)\end{array}$ & $\begin{array}{l}0.760 * * \\
(-3.67)\end{array}$ & $\begin{array}{l}0.755 * * \\
(-3.51)\end{array}$ \\
\hline Age 61-67 & & $\begin{array}{l}0.568^{* *} \\
(-4.76)\end{array}$ & $\begin{array}{l}0.570^{* *} \\
(-4.73)\end{array}$ & $\begin{array}{l}0.568^{* *} \\
(-4.76)\end{array}$ & $\begin{array}{l}0.568^{* *} \\
(-4.76)\end{array}$ & $\begin{array}{l}0.526 * * \\
(-5.02)\end{array}$ \\
\hline $\begin{array}{l}\text { Self-perceived general health } \\
\text { ('fair or worse') }\end{array}$ & & $\begin{array}{l}1.379 * * \\
(3.87)\end{array}$ & $\begin{array}{l}1.379 * * \\
(3.87)\end{array}$ & $\begin{array}{l}1.378^{* *} \\
(3.87)\end{array}$ & $\begin{array}{l}1.380 * * \\
(3.88)\end{array}$ & $\begin{array}{l}1.354^{* *} \\
(3.43)\end{array}$ \\
\hline Years of education & & $\begin{array}{l}0.979 * \\
(-2.08)\end{array}$ & $\begin{array}{l}0.980 * \\
(-2.01)\end{array}$ & $\begin{array}{l}0.979 * \\
(-2.11)\end{array}$ & $\begin{array}{l}0.980^{*} \\
(-1.96)\end{array}$ & $\begin{array}{l}0.984 \\
(-1.44)\end{array}$ \\
\hline Job tenure (years) & & $\begin{array}{l}0.964^{* *} \\
(-3.65)\end{array}$ & $\begin{array}{l}0.964 * * \\
(-3.66)\end{array}$ & $\begin{array}{l}0.964 * * \\
(-3.64)\end{array}$ & $\begin{array}{l}0.964^{* *} \\
(-3.69)\end{array}$ & $\begin{array}{l}0.961 * * \\
(-3.81)\end{array}$ \\
\hline Job tenure (years squared) & & $\begin{array}{l}1.001^{* *} \\
(3.18)\end{array}$ & $\begin{array}{l}1.001^{* *} \\
(3.17)\end{array}$ & $\begin{array}{l}1.001^{* *} \\
(3.18)\end{array}$ & $\begin{array}{l}1.001^{* *} \\
(3.20)\end{array}$ & $\begin{array}{l}1.001^{* *} \\
(3.36)\end{array}$ \\
\hline Workplace characteristics & & & & & & \\
\hline Fixed-term contract & & $\begin{array}{l}3.964^{* *} \\
(13.18)\end{array}$ & $\begin{array}{l}3.957^{* *} \\
(13.16)\end{array}$ & $\begin{array}{l}3.970 * * \\
(13.18)\end{array}$ & $\begin{array}{l}3.946^{* *} \\
(13.13)\end{array}$ & $\begin{array}{l}3.957 * * \\
(12.05)\end{array}$ \\
\hline Part-time employment & & $\begin{array}{l}1.036 \\
(0.39)\end{array}$ & $\begin{array}{l}1.035 \\
(0.39)\end{array}$ & $\begin{array}{l}1.035 \\
(0.38)\end{array}$ & $\begin{array}{l}1.038 \\
(0.41)\end{array}$ & $\begin{array}{l}1.043 \\
(0.44)\end{array}$ \\
\hline Public sector employment & & $\begin{array}{l}0.877 \\
(-1.63)\end{array}$ & $\begin{array}{l}0.880 \\
(-1.58)\end{array}$ & $\begin{array}{l}0.876 \\
(-1.64)\end{array}$ & $\begin{array}{l}0.882 \\
(-1.55)\end{array}$ & $\begin{array}{l}0.928 \\
(-0.89)\end{array}$ \\
\hline Less than 25 employees $^{\mathrm{b}}$ & & 1.000 & 1.000 & 1.000 & 1.000 & 1.000 \\
\hline 25-199 employees & & $\begin{array}{l}0.877 \\
(-1.64)\end{array}$ & $\begin{array}{l}0.878 \\
(-1.63)\end{array}$ & $\begin{array}{l}0.877 \\
(-1.64)\end{array}$ & $\begin{array}{l}0.879 \\
(-1.61)\end{array}$ & $\begin{array}{l}0.885 \\
(-1.44)\end{array}$ \\
\hline
\end{tabular}




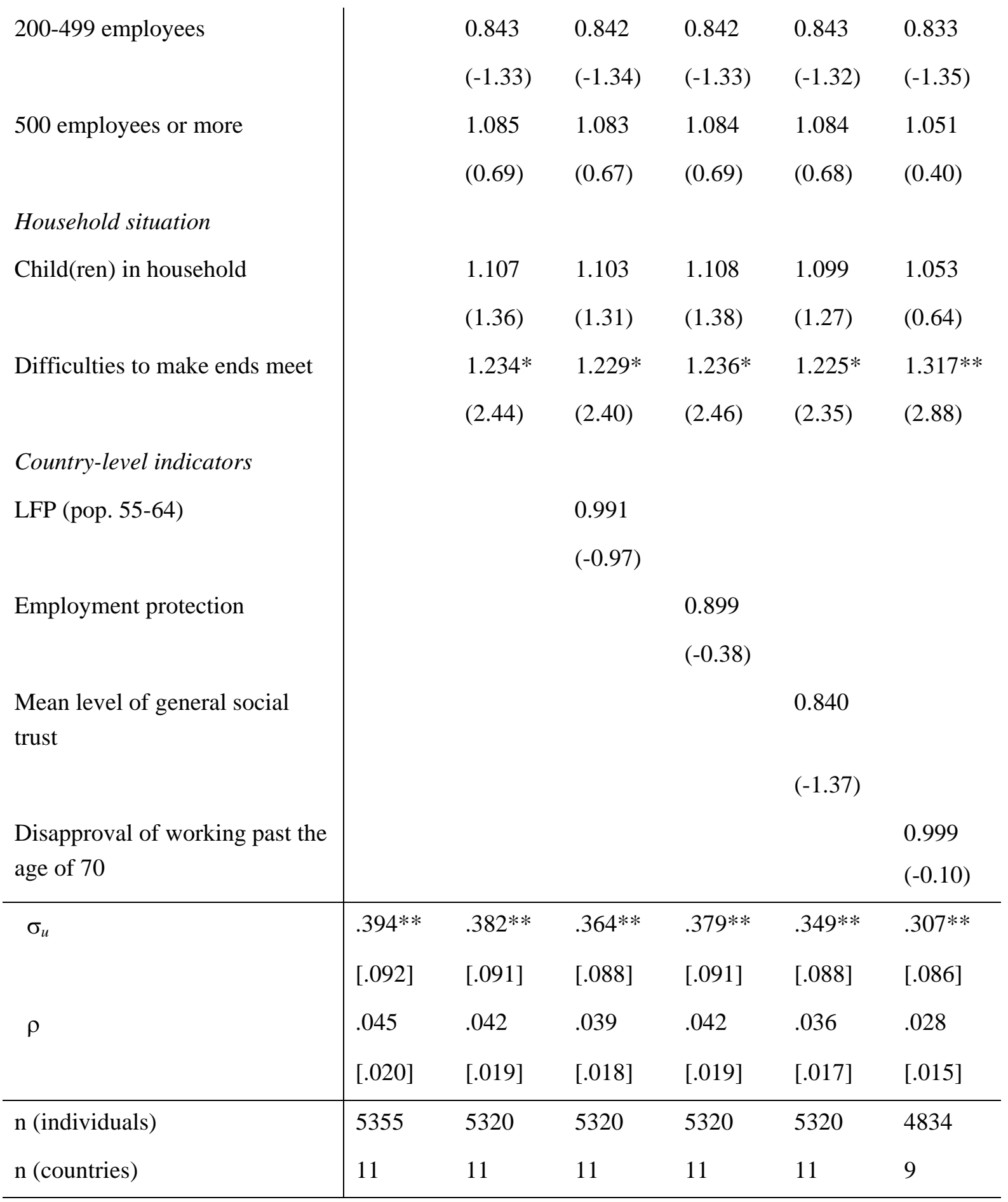

Source: SHARE 2004 (Release 2.0.1), authors' calculations. ${ }^{a}$ Results are displayed as odds ratios with t-statistics in parentheses. For $\sigma_{u}$ and $\rho$ we report standard errors in brackets. ${ }^{b}$ Reference category.

Significance: ${ }^{* *} \mathrm{p}<0.01,{ }^{*} \mathrm{p}<0.05$ 


\section{Notes}

${ }^{1}$ See Pichler \& Wallace (forthcoming) for related research investigating the reasons for differences in job satisfaction across Europe.

${ }^{2}$ Unfortunately, our data source does not cover any country representing a 'liberal' welfare state regime, such as the United Kingdom. However, a recent analysis of data from the European Social Survey suggests that the average level of self-perceived job security in the UK labour force is fairly close to the Continental European average (see Erlinghagen, 2008: Table 1). That is, we are unlikely to miss one of the potentially very informative cases at the upper or lower end of the distribution (see Banks \& Casanova, 2003, as well as Whiting, 2005, for overviews of older workers' employment situation in the UK).

${ }^{3}$ The lack of a suitable instrument prohibits us from estimating a Heckman-type selection model, which would allow us to address this issue econometrically.

${ }^{4}$ Further data were collected in 2005-06 in Israel. However, the currently available release of these data is a preliminary one and was therefore not considered in our analysis.

${ }^{5}$ Further potentially relevant country-level variables, such as the unemployment rate in the older population (economic reference frame), a measure of trust in political institutions (cultural reference frame), or the KOF index of social globalisation (social reference frame), were employed in alternative estimations. These, however, did not provide a better fit than those models on which the analyses whose details we present here are based. - The results of the alternative model specifications are available from the authors upon request.

${ }^{6}$ In multilevel analysis, the higher-level sample size often constitutes a major restriction. The question of what constitutes a sufficient sample size for accurate estimation is thus an important issue. While the multilevel literature does not provide a definite answer to this question, the number of countries in our study clearly marks the minimum number of necessary group-level observations (cf. Snijders \& Bosker, 1999: 44; also see the critical discussion in Maas \& Hox, 2005). 


\section{Discussion Paper Series}

Mannheim Research Institute for the Economics of Aging, Universität Mannheim

To order copies, please direct your request to the author of the title in question.

\begin{tabular}{|c|c|c|c|}
\hline Nr. & Autoren & Titel & Jahr \\
\hline $163-08$ & Martin Salm & Job loss does not cause ill health & 08 \\
\hline $164-08$ & $\begin{array}{l}\text { Martin Salm, Daniel } \\
\text { Schunk }\end{array}$ & $\begin{array}{l}\text { The role of childhood health for the inter- } \\
\text { generational transmission of human capital: } \\
\text { Evidence from administrative data }\end{array}$ & 08 \\
\hline $165-08$ & Christina Benita Wilke & $\begin{array}{l}\text { On the feasibility of notional defined contribution } \\
\text { systems: The German case }\end{array}$ & 08 \\
\hline $166-08$ & $\begin{array}{l}\text { Alexander Ludwig } \\
\text { Michael Reiter }\end{array}$ & $\begin{array}{l}\text { Sharing Demographic Risk - Who is Afraid of } \\
\text { the Baby Bust? }\end{array}$ & 08 \\
\hline 167-08 & $\begin{array}{l}\text { Jürgen Maurer } \\
\text { André Meier }\end{array}$ & $\begin{array}{l}\text { Smooth it Like the "Joneses?" Estimating Peer- } \\
\text { Group Effects in Intertemporal Consumption } \\
\text { Choice }\end{array}$ & 08 \\
\hline $168-08$ & $\begin{array}{l}\text { Melanie Lührmann } \\
\text { Jürgen Masurer }\end{array}$ & $\begin{array}{l}\text { Who wears the trousers? A semiparametric } \\
\text { analysis of decision power in couples }\end{array}$ & 08 \\
\hline $170-08$ & Jürgen Maurer & $\begin{array}{l}\text { Who has a clue to preventing the flu? } \\
\text { Unravelling supply and demand effects on the } \\
\text { take-up of influenza vaccinations }\end{array}$ & 08 \\
\hline $171-08$ & $\begin{array}{l}\text { Johannes Binswanger } \\
\text { Daniel Schunk }\end{array}$ & $\begin{array}{l}\text { What Is an Adequate Standard of Living } \\
\text { during Retirement? }\end{array}$ & 08 \\
\hline $172-08$ & $\begin{array}{l}\text { Mathis Schröder } \\
\text { Axel Börsch-Supan }\end{array}$ & Retrospective Data Collection in Europe & 08 \\
\hline $173-09$ & Michael Ziegelmeyer & $\begin{array}{l}\text { Documentation of the logical imputation using } \\
\text { the panel structure of the 2003-2008 German } \\
\text { SAVE Survey }\end{array}$ & 09 \\
\hline $174-09$ & $\begin{array}{l}\text { Axel Börsch-Supan, } \\
\text { Tabea Bucher-Koenen, } \\
\text { Martin Gasche und } \\
\text { Christina Benita Wilke }\end{array}$ & $\begin{array}{l}\text { Ein einheitliches Rentensystem für } \\
\text { Ost- und Westdeutschland - } \\
\text { Simulationsrechnungen zum Reformvorschlag } \\
\text { des Sachverständigenrates }\end{array}$ & 09 \\
\hline $175-09$ & $\begin{array}{l}\text { Steffen Reinhold, } \\
\text { Hendrik Jürges }\end{array}$ & Parental Income and Child Health in Germany & 09 \\
\hline $176-09$ & $\begin{array}{l}\text { Karsten Hank, Marcel } \\
\text { Erlinghagen }\end{array}$ & $\begin{array}{l}\text { Perceptions of Job Security in Europe's Ageing } \\
\text { Workforce }\end{array}$ & 09 \\
\hline
\end{tabular}

